\title{
Evaluation of national parks on the basis of Nature 2000 areas
}

\section{Parki narodowe w systemie obszarów natura 2000}

${ }^{*}$ Ph.D. Eng. Institute of Environmental Protection-National Research

Institute, Krucza 5/11d St., 00-548 Warsaw

Keywords: national parks, Nature 2000, standard data forms

Słowa kluczowe: parki narodowe, Natura 2000, standardowe formularze danych

\begin{abstract}
The goal of this work is to present the valorisation of national park based on the criteria resulting from standard data forms (SDF). The analysis covered a number of areas protected under the Birds Directive and Habitats Directive with the A, B or C category. Habitats and species marked as D in the SDF are not protected in the Nature 2000 areas, which is why they were not taken into account in the analysis. The presented characteristics made it possible to determine the hierarchy of national parks amongst the most valuable natural objects that deserve protection in the first place and also to verify the views on most valuable areas.
\end{abstract}

(c) IOŚ-PIB

\section{INTRODUCTION}

Both national parks and Nature 2000 areas are amongst the nature protection forms applied in Poland that overlap, that is, all national parks in Poland (23 parks) are also Nature 2000 areas. These areas are varied. Some of them result from the Birds Directive (Special Bird Protection Areas PLB) or the Habitats Directive (Special Habitat Protection Areas PLH) or from both directives combined. National parks are forms of nature protection that are relatively well recognised when it comes to the environmental values, thanks to the works related to the completion of Nature 2000 standard data forms (SDF) for areas having national parks within their limits. The collected data make it possible to evaluate individual objects based on the environmental valorisation that, according to Baryła [1995], is a hierarchical arrangement of a body of the selected category of natural objects attained with the use of selected criteria, that is, features and components, and the highlighting of natural values of such objects.

\section{GOAL OF THE WORK}

The goal of this work is to present the valorisation of national parks based on the criteria resulting from SDF completed for each Nature 2000 area. SDF contain the entire most important information relating to species and habitats occurring in Nature 2000 covered area. Additionally, they contain the evaluation of the importance of the area with regard to habitats and individual species covered with the protection type A, B, C or D. Valorisation results will make it possible to determine the hierarchy of national

\section{Streszczenie}

Celem opracowania jest przedstawienie waloryzacji parków narodowych w oparciu o kryteria wynikające ze standardowych formularzy danych. Analizie została poddana liczba przedmiotów ochrony wynikających z dyrektywy ptasiej i siedliskowej o ocenie A, B lub C. Siedliska i gatunki oznaczone w SDF jako D nie są przedmiotem ochrony danego obszaru Natura 2000, dlatego też nie uwzględnione zostały w analizie. Przedstawiona charakterystyka pozwoliła ustalić hierarchię parków narodowych wśród najcenniejszych obiektów przyrodniczych, które w pierwszej kolejności zasługują na zabezpieczenie i ochronę, a także pozwoliła zweryfikować poglądy na temat obszarów najbardziej cennych.

parks amongst the most valuable natural objects in our country deserving safety and protection in the first place. One has to be aware that each national park constitutes a unique and exceptional natural and cultural value.

\section{WORK METHODOLOGY}

The adopted valorisation criteria for national parks were the data contained in the SDF for appropriate Nature 2000 areas (PLB, PLH, PLC) relating to: (1) habitats, (2) birds, (3) mammals, (4) amphibians and reptiles, (5) fish, (6) invertebrates and (7) plants (Table 1). In the evaluation of national parks, when it comes to the representativeness of a natural habitat, habitats taken into account were marked in the SDF as A, excellent; B, good; and $C$, significant. As in the case of the evaluation of the population, only those populations that were marked in the SDF as A, 100\% $\geq p>15 \% ; B, 15 \% \geq p>2 \%$; and C, $2 \% \geq p>0 \%$ were taken into account. One point was assigned for each habitat and species (with the general evaluation of the area $A / B / C$ ). In turn, habitats and populations marked as $\mathrm{D}$ are not protected according to the opinion of the Ombudsman of the EC General Court of Justice, which is why they were not taken into account in the analysis. National parks cover the entire Nature 2000 area or its part (Table 2). Irrespective of the part of the Nature 2000 area covered by a national park, data for the Nature 2000 area were applied for valorisation purposes. This solution can entail a certain error, especially in the case of a national park that constitutes a small 


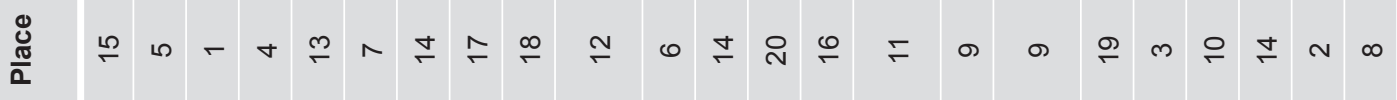

$$
\begin{aligned}
& \text { 制音 } \\
& \frac{0}{\frac{0}{0}} \\
& n \text { ก }
\end{aligned}
$$

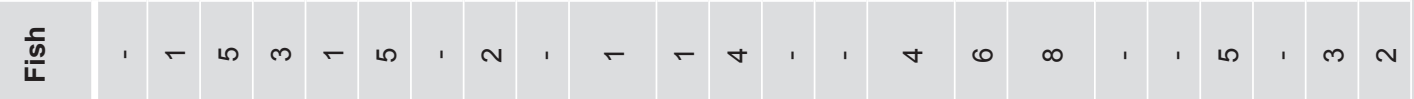

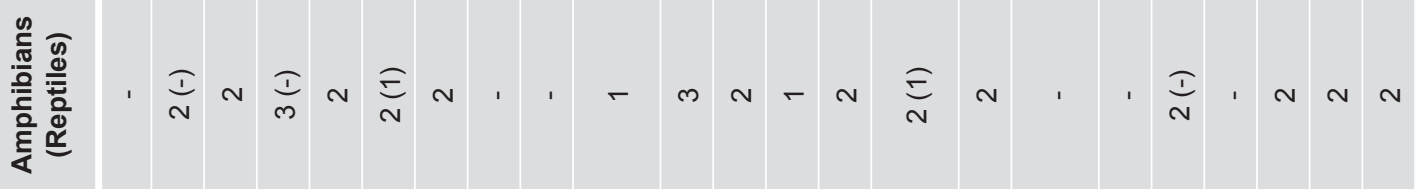

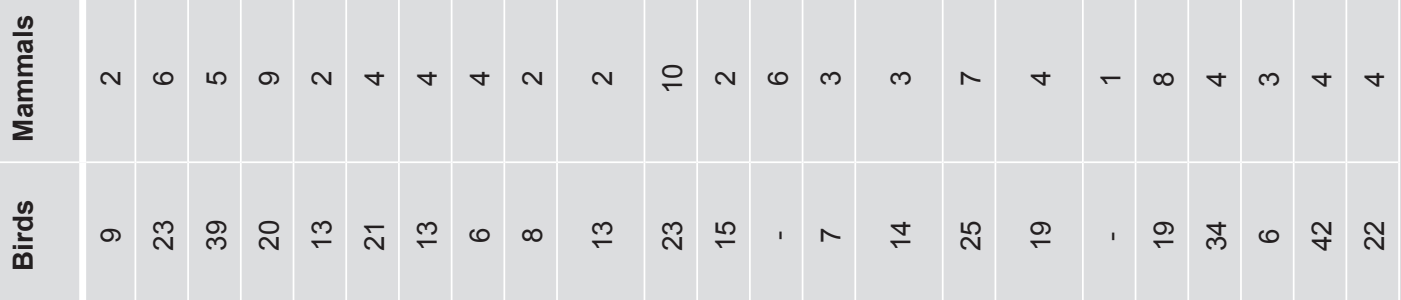

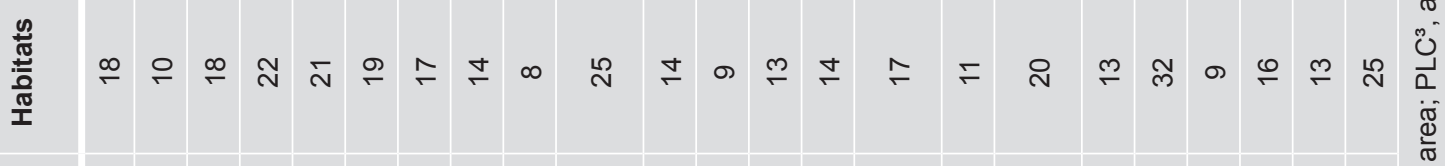

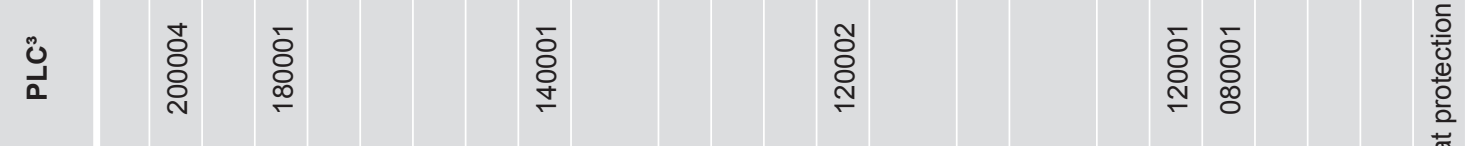

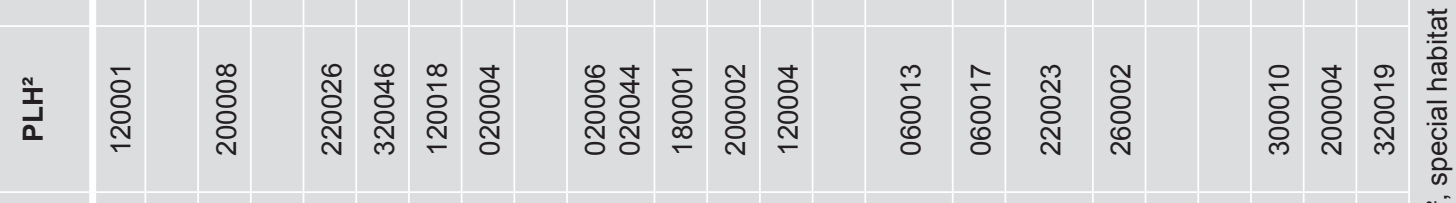

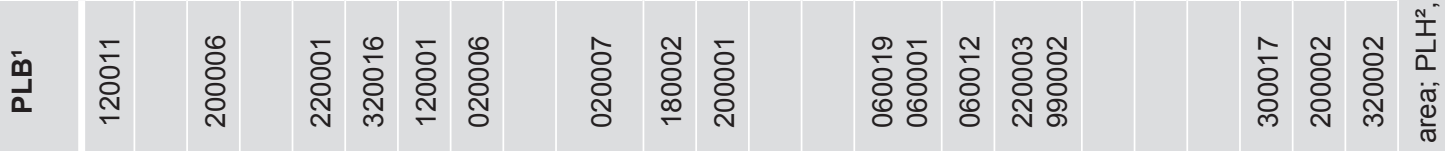

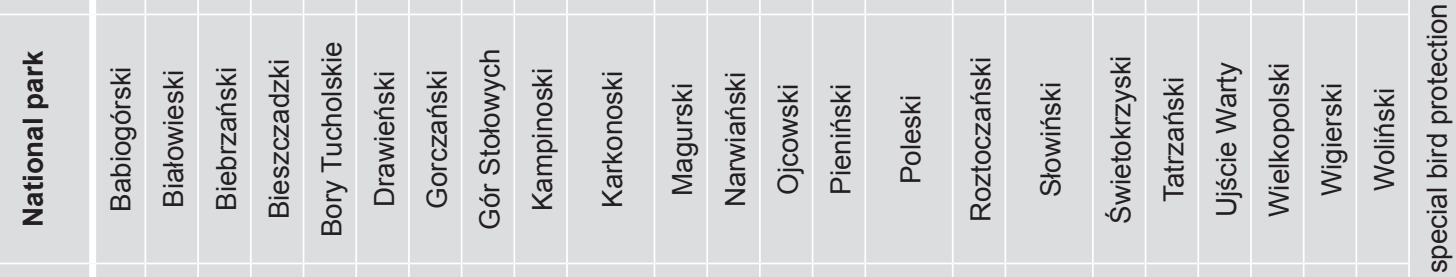

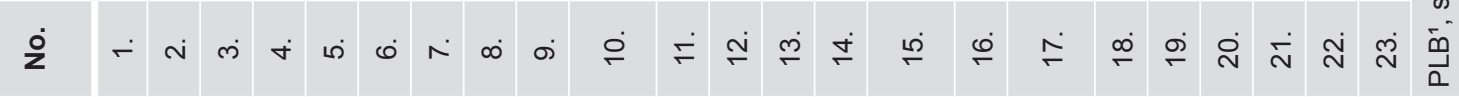


Table 2. Percentage of the area of national parks in Nature 2000 areas.

\begin{tabular}{|c|c|c|c|c|c|c|c|}
\hline No. & National park & PLB $^{1}$ & NP share in $\%$ & PLH $^{2}$ & NP share in $\%$ & PLC $^{3}$ & NP share in $\%$ \\
\hline 1. & Babiogórski & 120011 & 69 & 120001 & 100 & & \\
\hline 2. & Białowieski & & & & & 200004 & 17 \\
\hline 3. & Biebrzański & 200006 & 40 & 200008 & 49 & & \\
\hline 4. & Bieszczadzki & & & & & 180001 & 26 \\
\hline 5. & Bory Tucholskie & 220001 & 12 & 220026 & 62 & & \\
\hline 6. & Drawieński & 320016 & 6.06 & 320046 & 3.99 & & \\
\hline 7. & Gorczański & 120001 & 100 & 120018 & 38.9 & & \\
\hline 8. & Gór Stołowych & 020006 & 32 & 020004 & 57.73 & & \\
\hline 9. & Kampinoski & & & & & 140001 & 100 \\
\hline 10. & Karkonoski & 020007 & 31.97 & $\begin{array}{l}020006 \\
020044\end{array}$ & $\begin{array}{c}32.63 \\
0.8\end{array}$ & & \\
\hline 11. & Magurski & 180002 & 13 & 180001 & 97 & & \\
\hline 12. & Narwiański & 200001 & 100 & 200002 & 100 & & \\
\hline 13. & Ojcowski & & & 120004 & 100 & & \\
\hline 14. & Pieniński & & & & & 120002 & 100 \\
\hline 15. & Poleski & $\begin{array}{l}060019 \\
060001\end{array}$ & $\begin{array}{l}42.01 \\
99.19\end{array}$ & 060013 & 95.44 & & \\
\hline 16. & Roztoczański & 060012 & 8.2 & 060017 & 100 & & \\
\hline 17. & Słowiński & $\begin{array}{l}220003 \\
990002\end{array}$ & $\begin{array}{c}98.87 \\
5.73\end{array}$ & 220023 & 99.35 & & \\
\hline 18. & Świętokrzyski & & & 260002 & 93.8 & & \\
\hline 19. & Tatrzański & & & & & 120001 & 100 \\
\hline 20. & Ujście Warty & & & & & 080001 & 24.25 \\
\hline 21. & Wielkopolski & 300017 & 35 & 300010 & 90.3 & & \\
\hline 22. & Wigierski & 200002 & 11 & 200004 & 94 & & \\
\hline 23. & Woliński & 320002 & 70 & 320019 & 35 & & \\
\hline
\end{tabular}

$\mathrm{PLB}^{1}$, Special bird protection areas; $\mathrm{PLH}^{2}$, Special habitat protection areas; $\mathrm{PLC}^{3}$, 'bird' and 'habitat' protection areas combined. The following areas were omitted because of the minor share of the Park area in the Nature 2000 areas: PLH120033 (0.01\%), PLH180052 (0.03\%), PLH180015 (1\%), PLH180014 (0.01\%).

part of a Nature 2000 area. In particular, it applies to the following national parks: Drawieński (PLB 6.06\%), Wigierski (PLB 11\%), Bory Tucholskie (PLB 12\%), Magurski (PLB 13\%), Roztoczański (PLB 8.2\%), Białowieski (PLC 17\%), Ujście Warty (PLC 24.25\%), Bieszczadzki (PLC 26\%) and Karkonoski (PLB 32\% and PLH $33 \%)$.

\section{RESULTS AND CONCLUSIONS}

Attempts at the valorisation of national parks have been made before [Denisiuk 1992]. Denisiuk's Walory przyrodniczokrajobrazowe parków narodowych w Polsce are based on the comparison of 17 natural features determined, to a great degree, with the use of subjective methods. These features are (1) the variety of biocoenoses, (2) the presence of unique plant communities, (3) the richness of plant species, (4) the richness of protected plant species, (5) the presence of unique plant species, (6) the richness of animal species, (7) the richness of protected animal species, (8) the presence of unique animal species, (9) degree of living nature preservation, (10) degree of natural habitats preservation, (11) diversity of the physical composition, (12) landscape diversity, (13) presence of unique elements of the landscape, (14) attractiveness for tourists, (15) resistance of the environment to anthropogenic impact, (16) surface area category, (17) percentage share of the strictly protected area. Each characteristic was valorised at a 7-degree scale. A higher 
Table 3. Natural values of national parks according to Denisiuk (1992), partly changed

\begin{tabular}{|c|c|c|c|c|c|c|c|c|c|c|c|c|c|c|c|c|c|c|c|c|c|}
\hline \multirow{2}{*}{ No. } & \multirow{2}{*}{ National park } & \multicolumn{18}{|c|}{ Natural values in degrees $1-7^{1}$} & \multirow{2}{*}{$\begin{array}{c}\text { Total } \\
\text { score } \\
1-17\end{array}$} & \multirow[b]{2}{*}{ Place } \\
\hline & & 1 & 2 & 3 & 4 & 5 & 6 & 7 & 8 & 9 & 10 & 11 & 12 & 13 & 14 & 15 & 16 & 17 & 18 & & \\
\hline 1. & Woliński NP & 6 & 5 & 6 & 5 & 4 & 4 & 3 & 5 & 4 & 4 & 4 & 5 & 6 & 5 & 4 & 3 & 1 & 4,4 & 74 & 13 \\
\hline 2. & Słowiński NP & 7 & 7 & 6 & 5 & 6 & 3 & 6 & 4 & 6 & 7 & 3 & 5 & 7 & 7 & 3 & 6 & 5 & 5,5 & 93 & 5 \\
\hline 3. & Drawieński NP & 7 & 5 & 5 & 4 & 5 & 5 & 4 & 4 & 5 & 5 & 3 & 6 & 6 & 6 & 5 & 5 & 1 & 4,8 & 81 & 10 \\
\hline 4. & Wigierski NP & 7 & 5 & 6 & 7 & 4 & 5 & 3 & 6 & 5 & 6 & 3 & 5 & 6 & 6 & 5 & 5 & 1 & 5,0 & 85 & 9 \\
\hline 5. & Wielkopolski NP & 4 & 5 & 7 & 5 & 6 & 6 & 7 & 5 & 3 & 5 & 3 & 5 & 6 & 5 & 3 & 4 & 1 & 4,7 & 80 & 11 \\
\hline 6. & Kampinoski NP & 3 & 5 & 4 & 4 & 4 & 5 & 5 & 7 & 4 & 4 & 2 & 4 & 5 & 4 & 3 & 7 & 3 & 4,3 & 73 & 14 \\
\hline 7. & Białowieski NP & 5 & 6 & 7 & 7 & 5 & 6 & 7 & 7 & 7 & 7 & 1 & 3 & 5 & 7 & 4 & 4 & 7 & 5,6 & 95 & 4 \\
\hline 8. & Poleski NP & 7 & 7 & 7 & 7 & 7 & 6 & 6 & 4 & 6 & 4 & 2 & 6 & 7 & 4 & 3 & 3 & 3 & 5,2 & 89 & 6 \\
\hline 9. & Karkonoski NP & 4 & 7 & 6 & 3 & 5 & 5 & 5 & 4 & 3 & 5 & 6 & 7 & 7 & 7 & 3 & 4 & 5 & 5,1 & 86 & 8 \\
\hline 10. & Świętokrzyski NP & 3 & 7 & 5 & 5 & 1 & 5 & 6 & 4 & 5 & 5 & 5 & 6 & 6 & 5 & 5 & 4 & 4 & 5,1 & 87 & 7 \\
\hline 11. & Roztoczański NP & 7 & 5 & 5 & 6 & 5 & 4 & 7 & 5 & 4 & 4 & 3 & 4 & 3 & 4 & 4 & 4 & 2 & 4,5 & 76 & 12 \\
\hline 12. & Ojcowski NP & 2 & 6 & 7 & 7 & 6 & 4 & 6 & 6 & 3 & 4 & 5 & 7 & 7 & 7 & 4 & 2 & 4 & 5,1 & 87 & 7 \\
\hline 13. & Babiogórski NP & 3 & 7 & 5 & 4 & 7 & 5 & 4 & 6 & 6 & 6 & 6 & 7 & 7 & 7 & 6 & 2 & 7 & 5,6 & 95 & 4 \\
\hline 14. & Tatrzański NP & 7 & 7 & 7 & 7 & 7 & 7 & 7 & 7 & 6 & 7 & 7 & 7 & 7 & 7 & 6 & 7 & 7 & 6,9 & 117 & 1 \\
\hline 15. & Gorczański NP & 2 & 4 & 4 & 1 & 5 & 4 & 5 & 4 & 3 & 3 & 5 & 5 & 4 & 4 & 4 & 4 & 3 & 3,8 & 64 & 15 \\
\hline 16. & Pieniński NP & 2 & 7 & 7 & 6 & $t$ & 7 & 1 & 6 & 6 & 7 & 7 & 7 & 7 & 7 & 6 & 3 & 5 & 6,1 & 104 & 2 \\
\hline 17. & Bieszczadzki NP & 3 & 7 & 6 & 5 & 7 & 6 & 7 & 7 & 6 & 6 & 6 & 6 & 7 & 7 & 6 & 7 & 3 & 6,0 & 102 & 3 \\
\hline
\end{tabular}

${ }^{1} \mathrm{~A}$ higher number reflects a greater value of a park. Natural values: 1 , the variety of biocoenoses; 2 , the presence of unique plant communities; 3 , the richness of plant species; 4 , the richness of protected plant species; 5 , the presence of unique plant species; 6 , the richness of animal species; 7 , the richness of protected animal species; 8 , the presence of unique animal species; 9 , degree of living nature preservation; 10, degree of natural habitats preservation, 11, diversity of the physical composition; 12, landscape diversity; 13 , presence of unique elements of the landscape; 14, attractiveness for tourists; 15 , resistance of the environment to anthropogenic impact; 16, surface area category; 17, percentage share of the strictly protected area; 18, average from 1 to 17.

digit refers to a greater value of a characteristic. Results of the valorisation according to Denisiuk [1992] are presented in Table 3. Even though the criteria were different for both valorisations, the comparison of results shows a great similarity of parts of national parks in the occupied position. It is particularly true for our most valuable objects: Tatrzański National Park (in first position according to Denisiuk and the third one according to abovementioned authors), Bieszczadzki National Park (in third and fourth positions) and the Białowieski National Park (fourth and fifth positions). The first position amongst national parks currently belongs to the Biebrzański National Park (85 points). This high position can be overestimated as the share of that park in Nature 2000 areas does not exceed $50 \%$ of their area. The second position of the Wigierski National Park is also overestimated because data for the entire PLB200002 were adopted even

\section{REFERENCES}

DENISIUK Z. 1992. Walory przyrodniczo-krajobrazowe parków narodowych w Polsce. Parki Narodowe i Rezerwaty Przyrody, 11(2,3); 5-15.

BARYŁA J. 1995. Waloryzacja, wartości przyrodnicze oraz problemy ochrony jaskiń Pienińskiego Parku Narodowego, Pieniny - Przyroda i Człowiek, 3; 51-57. though the park occupies only $11 \%$ of that area. When analysing points within the PLB and PLH areas separately, positions of individual national parks are presented as follows. National parks considered most valuable because of the variety of bird species (PLB) include Wigierski NP (42 species), Biebrzański NP (39) and the Ujście Warty NP (34). National parks most valuable because of the richness of habitats and species (PLH) include Tatrzański NP (50 habitats and species), Bieszczadzki NP (48), Biebrzański NP (46) and Białowieski NP (42). Despite certain simplifications and generalisations resulting from the varied share of park areas, the presented valorisation of national parks in Nature 2000 areas allows us to understand better the role and importance of individual areas for the country and also to verify the existing views on the subject amongst the public.

Opinion of Advocate-General Juliane Kokott presented on April 19, 2007. Case C-304/05 Commission of the European Communities vs. the Republic of Italy Standard Data Forms as at 30.08.2017. 